\title{
Ammonia Volatilization from Fertilizer Urea-A New Challenge for Agriculture and Industry in View of Growing Global Demand for Food and Energy Crops
}

\author{
Maria Skorupka ${ }^{1,2}$ and Artur Nosalewicz ${ }^{1, *(\mathbb{D})}$ \\ 1 Institute of Agrophysics Polish Academy of Sciences, Doświadczalna 4, 20-290 Lublin, Poland; \\ m.skorupka@ipan.lublin.pl \\ 2 Grupa Azoty Zakłady Azotowe "Puławy" S.A., al. Tysiąclecia Państwa Polskiego 13, 24-110 Puławy, Poland \\ * Correspondence: a.nosalewicz@ipan.lublin.pl; Tel.: +48-81-744-50-61
}

check for updates

Citation: Skorupka, M.; Nosalewicz, A. Ammonia Volatilization from Fertilizer Urea-A New Challenge for Agriculture and Industry in View of Growing Global Demand for Food and Energy Crops. Agriculture 2021, 11, 822. https://doi.org/ 10.3390/agriculture11090822

Academic Editors: Pavel Krasilnikov, Miguel A. Taboada and Amanullah

Received: 19 July 2021

Accepted: 26 August 2021

Published: 29 August 2021

Publisher's Note: MDPI stays neutral with regard to jurisdictional claims in published maps and institutional affiliations.

Copyright: (c) 2021 by the authors. Licensee MDPI, Basel, Switzerland. This article is an open access article distributed under the terms and conditions of the Creative Commons Attribution (CC BY) license (https:// creativecommons.org/licenses/by/ $4.0 /)$.

\begin{abstract}
The growing world population and the necessity to meet its nutritional needs despite the limited area of agricultural land pose a serious challenge for agriculture. Agriculture is responsible for $80-95 \%$ of total ammonia emissions to the atmosphere, but at the same time it has great potential to reduce them. Fertilisation with mineral nitrogen (in particular urea) is responsible for 19.0-20.3\% of total ammonia emissions emitted from agriculture. Ammonia emissions have a negative impact on the environment and human health, therefore it is important to minimize the volatilization of ammonia and increase fertiliser efficiency. This is important due to the need to mitigate the negative impact of anthropopressure on the environment in terms of air pollution, negative effect on soils and waters. The application of urease inhibitors during fertilisation with nitrogen fertilisers is one method to reduce ammonia emissions from plant production. Another option to achieve this goal is to reverse the global trend toward maximizing the production of energy crops (intensive fertilisation inevitably increasing ammonia emissions to the environment) for the production of biofuels, which is growing rapidly, taking up arable land that could be used for food production. The aim of the review is to identify the impact of recently introduced technologies for reducing ammonia emissions from urea on agricultural productivity, environment, and crops. It is of importance to reconsider optimization of crop production in arable land, possible owing to the progress in the production, modification, and application of mineral fertilisers and changes in crop structure. A broad debate is necessary with policymakers and stakeholders to define new targets allowing introduction of technologies for conversion of energy crops into energy with a minimal impact on food production and environmental issue.
\end{abstract}

Keywords: ammonia emission; urease inhibitors; biofuels; food production; bioenergy crops; $\mathrm{N}$ fertilisers

\section{Introduction}

Urea is one of the most popular nitrogen fertilisers worldwide. It has high content of nitrogen (46\%) with very high bioavailability. However, it is characterized by a high degree of losses in contact with soil, in comparison with other fertilisers. $\mathrm{NH}_{3}$ emission per kilogram of urea converted to nitrogen ranges from 159 to $168 \mathrm{~g}$, depending on soil $\mathrm{pH}$ and climatic conditions [1]. This undesired ammonia emission is an economic problem resulting in reduction of crop yields due to nitrogen loss and has a negative long-term impact of agriculture expansion into the environment [2]. At the same time, the growing world population, and the need to meet global demand for food, make for a continuous increase in the production of fertilisers, including urea [3,4].

The necessity to reduce ammonia emission and the associated nitrogen losses from fertilisers introduced into soil, especially urea-based formulations, has resulted in the 
implementation of the National Emission Ceilings (NEC) Regulation (directive of the European parliament and of the council (EU) 2016/2284 of 14 December 2016) [5-7].

The reduction of ammonia emissions accompanying the application of urea fertilisers has recently been achieved by use of nitrogen conversion inhibitors (urease inhibitors) in the soil [8-10]. It should be noted that the global urea production in 2019 reached approximately 209 million tons and is systematically growing [3], with about 10\% produced in Europe [11]. Worldwide industrial urea production facilities (except for European installations which already meet the new requirements of European law [5-7]) are not adapted to the coating of urea granules with urease inhibitors. These installations require costly, technical changes to achieve this goal.

Moreover, urease inhibitors should have appropriate physico-chemical properties to be applicable at specific conditions both in the manufacture and application. Urease inhibitor-containing commercial mixtures currently released on the EU market are adapted to various forms of application, e.g., simultaneous application together with fertiliser in the field or coating of granules by the producer or the final client [12,13]. The use of separate fertiliser and inhibitor by the client might not ensure precise dosage. The current requirements of this technique assume a $70 \%$ average reduction of ammonia emissions for solid urea [13].

The emissions of ammonia or other gases from agricultural production may be additionally reduced by a change in the structure of plant production, which is one of the dilemmas faced by agriculture, e.g., raw materials for production of biofuels [14]. The dynamically growing production of energy crops (as raw materials for biofuels) is characterized by high fertiliser demands, resulting in associated ammonia emissions, and high pesticide applications $[15,16]$. The production of biofuels has been touted as a solution for mitigating the negative impact of fossil fuels on the environment. The expansion of biofuels leads to growth in the production of agricultural raw materials for biofuels and can indirectly lead to changes in land use structure [16].

Agriculture, being strongly linked to the conditions of industry that provides resources as well as processing capacities for agricultural products, must secure food production in the long term, despite changes in the environment affecting agricultural productivity in various regions of the world. [16] This should be attained with care for preserving the natural environment and ensuring appropriate amounts of produce for food and fodder. Thus, the aim of the review is to point out the impact of recently introduced policies and technologies aimed at limiting ammonia emission from urea fertiliser on agriculture productivity, including the use for the purposes of food and energy crops.

\section{Challenges to the Market of Agricultural Products}

Agriculture and other areas of human activity associated with food production will have to adapt to climate change and, at the same time, meet the future nutritional needs of the growing population. It is predicted that the world population will reach approximately 9.1 billion by $2050[17,18]$, with substantial population growth to be recorded in developing countries. Approximately $70 \%$ of the global population are expected to live in cities (vs. $49 \%$ today) and urbanization will proceed at an accelerated pace. To feed the increasing urban population, food production (excluding food raw materials that are currently used for production of biofuels) must increase considerably. The annual production of cereals and meat will have to increase to approximately 3 billion tons and 470 million tons, respectively $[17,18]$. Improvement of the standard of living will be accompanied by an approx. 30\% increase in the calorific value of consumed meals, compared to values recorded in 2015 [18]. Additionally, considering the expected expansion of agriculture by 2050, it will be necessary to convert 593 million ha of land into arable fields, with respect to the area of agricultural land in 2010 [17].

Climate change is one of the threats to the safety of long-term food supplies. An unresolved issue is the necessity to reduce the 11-gigaton greenhouse gas emissions produced in agriculture from the amounts predicted for 2050 to the level required to curb global 
warming below $2{ }^{\circ} \mathrm{C}$ (an indispensable level to prevent major negative climate change effects). Progressive climate change will force cultivation of heat-tolerant plants and induce other limitations to agriculture $[17,18]$. Increasing air temperature and its impact on soil wetness were shown to be main environmental drivers of ammonia emission [19].

\section{Emission of Ammonia from Agriculture}

Agriculture is the main source of ammonia emissions to the atmosphere. It is responsible for $80-95 \%$ of the total emissions of this gas, where mineral fertilisers account for $20.3 \%$, animal husbandry for $48.6 \%$, and biomass combustion for $13.3 \%$ of emissions, while fossil fuel combustion and industry account for $0.7 \%$ of emissions [20]. Ammonia emission is also strongly dependent on soil use, emissions from bare unfertilised soils are estimated at up to $3 \mathrm{~kg} \mathrm{~N}-\mathrm{NH}_{3} \cdot \mathrm{ha}^{-1}$.year ${ }^{-1}$ as compared to about $1.2 \mathrm{~kg} \mathrm{~N}-\mathrm{NH}_{3} \cdot \mathrm{ha}^{-1} \cdot$ year $^{-1}$ from forests [20]. It is expected that emission from uncultivated lands may increase due to increasing atmospheric $\mathrm{N}$ deposition [21].

Ammonia volatilization during mineral nitrogen fertilisation [9] accounts for $19.0-20.3 \%[19,20]$ of the percent of total ammonia emissions emitted from agricultural activities. Ammonia emission is an economic problem, resulting in reduction of crop yields due to nitrogen loss, and has a negative impact on the environment [8]. Gaseous ammonia emitted to the atmosphere enters a cycle of chemical transformations, which may ultimately cause negative effects on soil and water environments $[2,9,18,22]$ and degradation of susceptible ecosystems [2,23], leading to acidification of water and soils and eutrophication of natural terrestrial and aquatic ecosystems. As a consequence, these emissions exert adverse effects on the biodiversity of the entire ecosystem, including soil biodiversity, which is of fundamental importance for the evolution and durability of life-supporting systems in the biosphere [2,22]. $\mathrm{NH}_{3}$ is a secondary source of $\mathrm{N}_{2} \mathrm{O}$; thus, it is indirectly responsible for global warming and ozone depletion in the stratosphere, $\mathrm{N}_{2} \mathrm{O}$ is a GHG of high global warming potential [9,24-27]. Moreover, after fertiliser application in soil urea hydrolysis starts, which results in emission of not only ammonia but also $\mathrm{CO}_{2}$, especially when high doses of nitrogen fertilisers are used $[8,12,26]$.

\section{Fertiliser Consumption and Demand}

The growing demand for agricultural products, together with the growing world population size, has been stimulating the global production of fertilisers for years.

The total fertiliser consumption $\left(\mathrm{N}+\mathrm{P}_{2} \mathrm{O}_{5}+\mathrm{K}_{2} \mathrm{O}\right)$ in 2009 equal to $161 \mathrm{mln}$ tons increased to 184.7 million tons in 2014 and was predicted to reach 186.6 million tons in 2015 [3]. Forecasts of the world demand for nitrogen, phosphorus, and potassium $\left(\mathrm{N}+\mathrm{P}_{2} \mathrm{O}_{5}+\mathrm{K}_{2} \mathrm{O}\right)$ used as fertilisers assume a demand of 200.9 million tons in 2022 [4]. The data on fertiliser consumption in 2009-2015 [3] and predictions for 2022 [4] show a continuous increase in the demand for these products, whereas the International Fertilisers Association (IFA) outlook [11] for fertilisers predicts the use of 197 million tons in 2024. The latest forecast includes disruptions in 2020/21 due to the negative impact of COVID-19 on the global fertiliser supply chain, the global recession, the economic downturn and uncertainty about the pace of economic recovery, record-breaking unemployment figures, and size of global grain stocks [11].

\section{Production of Biofuels vs. Ammonia Emissions}

One of the important areas of agriculture is the cultivation of bioenergy crops for production of biofuels, i.e., biodiesel, HVO (hydrotreated vegetable oil), and ethanol. Biofuels are serious competitors for food plants and an indirect source of ammonia emission associated with the high fertiliser demands [14]; they occupy arable land that could be used for food production. Due to the high use of fertilisers and pesticides, production of energy crops adversely affects the environment and biodiversity $[26,28,29]$. The production of commonly used biofuels, such as rapeseed biodiesel and maize bioethanol, depending on the nitrogen doses applied, according to updated calculations, can contribute to global 
warming as much as energy production from fossil fuels [30]. Crops with less $\mathrm{N}$ demand have a more favourable effect on the climate change.

The global production of biofuels in 2018 reached 154-167.9 billion litres [15,31] and increased by approximately 10 billion litres compared to 2017 [31], whereas only 49.9 billion litres were produced in 2005. Biofuel production is predicted to increase by $25 \%$ between 2019 and 2024. The largest biofuel producers are China, Brazil, the USA, and the ASEAN countries [26,31]. In 2018, $16.1 \%$ of maize grain, $1.7 \%$ of wheat grain, $3.3 \%$ of other feed grains, and $13.5 \%$ of vegetable oil were processed into biofuels globally [15].

A strong shift in maize cultivation from the food sector to the biofuel sector can be seen from data shown in Figure 1. Maize production as raw materials for biofuels increased rapidly from 51.3 million tons of grain in 2005 up to 181.7 tons in 2018 when it occupied a cultivation area of 30.29 million ha [15]. A typical nitrogen dose for maize ranges between $150 \mathrm{~kg} \mathrm{~N} \mathrm{ha}^{-1}[10,32,33]$ and $240 \mathrm{~kg} \mathrm{~N} \mathrm{ha}^{-1}$ [32,34], which is equal to 5.2 million tons of $\mathrm{N}$ to 7.3 million tons of $\mathrm{N}$ in urea per year, (assuming maize production 181.7 million tons of grain as raw materials for biofuels). The nitrogen emission accompanying maize cultivation for biofuel production can be quite significant depending on the region, climate, and crop management. Maize is one of the three main primary crops (along with wheat and rice), which collectively account for $72 \%$ of $\mathrm{NH}_{3}$ emissions related to the use of mineral fertilisers in global agriculture [35]. At the same time, its requirements for nitrogen and pesticides are higher than in other crops [36]. Mineral fertilisers were found to be responsible for about $73 \%$ of all energy inputs in the production of maize [37]. However, high nitrogen rates have a negative impact on bioenergy crops. It was shown that the increasing $\mathrm{N}$ doses increased plant overall carbon content and specific biochemical compounds, e.g., lignin, which is an unfavourable component during ethanol production [38].
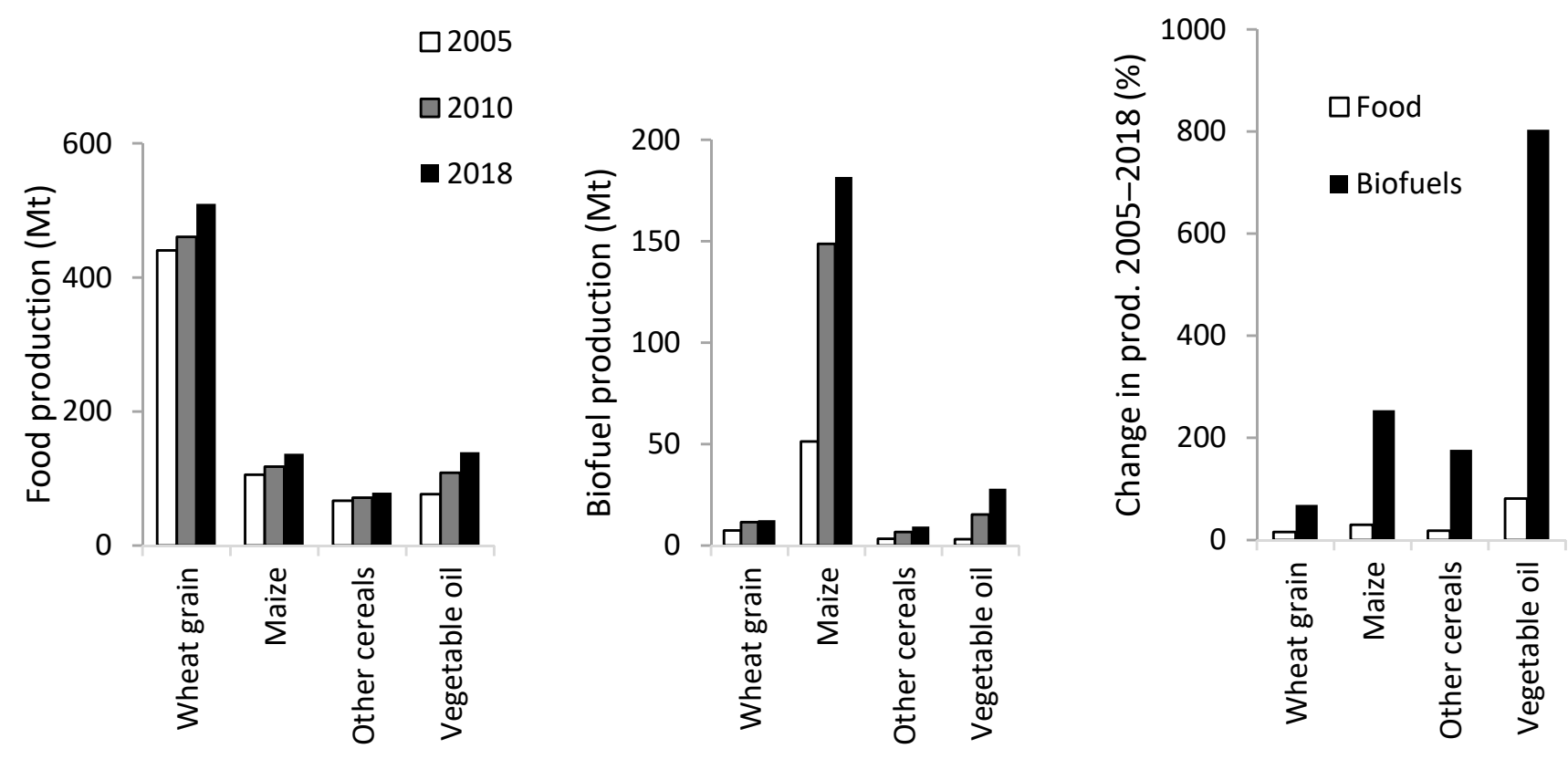

Figure 1. Production of agricultural raw materials for the food and biofuel sectors [15].

The development of biofuel markets is strongly related to the macroeconomic environment and, in particular, to the level of crude oil prices. Since the beginning of the 21st century, the development of global biofuel markets has been driven by policies supporting increased biofuel production and use. The government support for the biofuel industry ranges from tax policies to financial support for investment projects. On the other hand, there are trends where the cultivation of energy crops is beginning to be perceived as controversial [30] due to the uncertainty about net GHG savings and the potential competition with land use for biodiversity and food production. 
The possibility of reduction of net greenhouse gas emissions and ammonia emissions in the production and use of biofuels depends on the type of crop plants, the location with its specific climatic conditions, soil type and the level of nitrogen fertilisation. Some studies $[26,30]$ show that the GHG balance for the production of biofuels is questionable in comparison with that of fossil fuels, and real $\mathrm{N}_{2} \mathrm{O}$ emissions may be 2-3 times higher than those estimated from field measurements. Measurements of the net balance of greenhouse gases are encumbered with substantial uncertainty and largely depend on the plant species concerned, nitrogen fertiliser doses, soil conditions, climate, and agricultural management practice [26]. The potential reduction of ammonia emissions in cultivation of plants intended for biofuel production will improve its net GHG balance. Currently, the production of biofuels (especially first-generation liquid biofuels, bioethanol, and biodiesel) is responsible for emission of ammonia and greenhouse gases. To alleviate this problem, it is necessary to implement new technologies for converting agricultural biomass into energy, in particular, the biomass obtained without competing against food production. The use of new technologies to produce biofuels will reduce the consumption of nitrogen fertilisers and thus the emission of ammonia to the atmosphere. $[15,16]$. Analysis of land suitability for energy crops [39] shows that about $40 \%$ of land area suitable for bioenergy crops is area potentially suitable also for food production.

\section{Evaluation of Ammonia Emissions from Mineral Fertilisers with Focus on Urea}

Reported ammonia emission after application of nitrogen fertilisers differs in wide ranges depending on soil properties (moisture, density, $\mathrm{pH}$ ), climatic conditions, etc. The values of ammonia emission factors for temperate climate range from 159 to $168 \mathrm{~g}$ of nitrogen per $1 \mathrm{~kg}$ of applied urea, depending on soil $\mathrm{pH}$ and climatic conditions [1]. Emission of ammonia during and after the fertilisation process results in a loss of the fertiliser. It reduces the effectiveness of fertilisation and at the same time increases the costs of plant production. The ammonia emission factors determined [1] for a specific fertiliser usually reach the lowest values at natural $\mathrm{pH}$ and low temperatures, whereas their highest values are recorded at high $\mathrm{pH}$ and high temperatures. In the case of ammonium nitrate, depending on the soil $\mathrm{pH}$ in temperate climate, the $\mathrm{NH}_{3}$ emission per kilogram of applied ammonium nitrate converted to nitrogen is much lower ranging 16-33 $\mathrm{g}[1,40,41]$. Guidance from the UNECE Task Force on Reactive Nitrogen shows that NH3 emissions from urea-based fertilisers (typically $5-40 \% \mathrm{~N}$ loss as NH3) are much greater than those based on ammonium nitrate (typically $0.5-5 \% \mathrm{~N}$ loss as NH30 [13]. Noteworthy, nitrogen accounts for $32 \%$ in ammonium nitrate and $46 \%$ in urea; therefore, nitrate doses differ from urea doses for the same crops.

Application of urea into the soil may lead to high nitrogen gas losses amounting on average c.a. $18 \%$ of applied $\mathrm{N}$ [42]. However, very high $\mathrm{N}$ loses were often reported: $50 \%$ [43], 64\% [42], 82.4\% [44]. An increase in air temperature from approx. 2 to $30{ }^{\circ} \mathrm{C}$ was responsible for an increase in $\mathrm{N}$ losses from about 0 to $60 \%$ [45].

In field experiments on maize, $\mathrm{NH}_{3}$ emissions were shown to increase with increase in fertilisation rates (150 and $270-300 \mathrm{~kg} \mathrm{~N}^{-1}$ ); the emissions were responsible for 4-38\% and $18-61 \%$ of applied $N$ for lower and higher urea doses depending on soil type $[9,10,46]$.

Due to the high heterogeneity of soil properties, ammonia emissions from the soil immediately after fertilisation are characterized by considerable spatial and temporal variability. This has been confirmed by numerous reports showing a wide range of nitrogen losses through $\mathrm{NH}_{3}$ emissions at a level of $2-43 \%$ for arable land and $10-58 \%$ for grassland [12].

Although urea hydrolysis catalysed by the urease enzyme depends on temperature, emission from urea is affected by temperature and the effect is diminished by the enzymatic activity of the soil $[40,47]$, which is highly variable. 


\section{Urea Production Capacity and Process Limitations}

The global urea production capacity is approximately 209 million tons (2019) [11], (including $10 \%$ produced in Europe, with regulations already in place to limit ammonia emissions [5-7]). The currently constructed installations worldwide will have increased the global urea production capacity to $225 \mathrm{Mt}$ by the end of 2021, which implies an increase by $17 \mathrm{Mt}(+8 \%)$ to reach $230 \mathrm{Mt}$ in 2024. In 2019-2024, the production capacity is expected to increase in South Asia (mainly in India and Bangladesh), Africa (Nigeria and Egypt), Eastern Europe, and Central Asia (Russia and Uzbekistan), i.e., regions with no regulations on ammonia emission reduction. Urea demand is expected to rise in almost every region, but to a lesser extent in East Asia. South Asia will account for almost $25 \%$ of the potential global growth in the demand. Urea demand is also expected to increase significantly in Latin America and Africa. Forecasts suggest an increase in the proportion of urea to 2/3 of the production of all nitrogen fertilisers in medium-term prospects [11].

The operating and the newly constructed industrial facilities for urea production are characterized by high production capacities. Currently, installations based on proven technical solutions with a capacity of up to 3 million tons of urea per year are being built in the world. The construction of five such facilities is underway with varying degrees of advancement [48].

Commercial synthesis of urea involves reaction of ammonia with carbon dioxide at high pressure to form ammonium carbamate, which is then dehydrated by thermal treatment yielding urea and water [49]:

$$
2 \mathrm{NH}_{3}+\mathrm{CO}_{2} \underset{(a)}{\Leftrightarrow} \underbrace{\mathrm{NH}_{2} \mathrm{COONH}_{4}}_{\text {Ammonium carbamate }} \underset{(b)}{\Leftrightarrow} \mathrm{CO}\left(\mathrm{NH}_{2}\right)_{2}+\mathrm{H}_{2} \mathrm{O}
$$

Both reactions (1) take place in the liquid phase in the same reactor and are in equilibrium. Their performance depends on various process parameters. The most typical production conditions are presented in Table 1, which shows the high requirements of urea production. Reaction (a) is fast and exothermic, whereas reaction (b) is slower and endothermic. Usually, $50-80 \%$ conversion (based on $\mathrm{CO}_{2}$ ) is achieved. It increases with the rise in temperature and the $\mathrm{NH}_{3} / \mathrm{CO}_{2}$ ratio and decreases with the increasing $\mathrm{H}_{2} \mathrm{O} / \mathrm{CO}_{2}$ ratio [49].

Table 1. Typical process parameters of urea production [49].

\begin{tabular}{cc}
\hline Process Parameter & Process Values \\
\hline Pressure (bar) & $140-250$ \\
Temperature $\left({ }^{\circ} \mathrm{C}\right)$ & $180-210$ \\
$\mathrm{NH}_{3} / \mathrm{CO}_{2}$ ratio (molar) & $2.8: 1-4: 1$ \\
Retention time (minutes) & $20-30$ \\
\hline
\end{tabular}

The melting point of urea is $130{ }^{\circ} \mathrm{C}$, above which the compound is degraded. This property allows solidification of urea on an industrial scale at a slightly lower temperature than the melting point. The temperature determines the possibility of addition of e.g., a urease inhibitor, in accordance with the new EU regulations. It is recommended [13] to reduce ammonia emissions from urea-based fertilisers by using urease inhibitors, e.g., NBPT, mainly in liquid form for coating urea fertiliser granules [8]. Other recommended techniques to reduce ammonia from urea-based fertilisers include slow-release coatings, injection into soil, rapid incorporation into soil and irrigation immediately after application [13].

\section{Urease Inhibitors-Mechanism of Action}

Urea hydrolysis in soil with the involvement of urease results in intensive release of the ammonium form of nitrogen $\mathrm{NH}_{4}$ in the reaction:

$$
\left(\mathrm{NH}_{2}\right)_{2} \mathrm{CO} \text { (urea) }+2 \mathrm{H}_{2} \mathrm{O}+\mathrm{H}^{+} \text {(urease) } \leftrightarrow 2 \mathrm{NH}_{4}^{+}+\mathrm{HCO}_{3}^{-}
$$


which further proceeds as follows:

$$
\mathrm{H}_{4}^{+}=\mathrm{NH}_{3}+\mathrm{H}^{+} \mathrm{pKa}=9.25
$$

The equilibrium of this reaction depends on $\mathrm{pH}$ and temperature and shifts significantly towards the formation of $\mathrm{NH}_{3}$ at a higher $\mathrm{pH}$ value and a temperature rise. For example, the driving force (relative concentration of $\mathrm{NH}_{3}$ in the soil solution) of ammonia emission was assumed as 1 at $\mathrm{pH} 7$ and the temperature of $25^{\circ} \mathrm{C}$ but at $\mathrm{pH} 8$ and $20^{\circ} \mathrm{C}$ was assumed as 5 . This explains the $\mathrm{NH}_{3}$ loss $(7 \%)$ at soil $\mathrm{pH}$ not exceeding 7 , even if the temperature rises to $45^{\circ} \mathrm{C}$. In turn, the driving force at constant soil $\mathrm{pH}$ increases with temperature. It was reported that the driving force of ammonia emission at $\mathrm{pH} 8$ and a temperature of $30^{\circ} \mathrm{C}$ was three times lower than at $10^{\circ} \mathrm{C}[50]$.

$$
\mathrm{CO}_{3}^{-}+\mathrm{H}^{+} \leftrightarrow \mathrm{CO}_{2}+\mathrm{H}_{2} \mathrm{O}
$$

Uea nitrogen losses are also largely dependent on soil properties, e.g., the content of clay and sand fractions. The negatively charged surface of clay particles contributes to adsorption of $\mathrm{NH}_{4}{ }^{+}$. In turn, higher soil porosity associated with high sand content facilitates gas exchange between deeper soil and the atmosphere [51].

Various urease inhibitors are commercially available on the EU market. Table A1 (Appendix A) presents the chemical compositions of urease inhibitors for application through urea spraying treatments and material safety data sheets provided by the manufacturers. At present, the knowledge of the potential impact of chemicals used with $\mathrm{N}$ fertilisers to decrease urease activity on food safety is limited. The data on the composition of urea inhibitors may contribute to consumers' awareness of food safety; nevertheless, long-term effects should be evaluated to ensure positive reception of these new modified fertilisers [52].

$\mathrm{N}$-butyl thiophosphoric triamide (NBPT) is the most common active agent in commercial urease inhibitors used worldwide. A mixture of two compounds, i.e., NBPT (N-butylthiophosphoric triamide) and NPPT (N-propylphosphorothioic triamide), is used as well [53]. Currently, it is recommended that these commercially available urease inhibitors should be applied with urea in two forms: in the coatings of urea granules or liquid urease inhibitor solutions applied to the soil after urea fertilisation, which is associated with their physicochemical properties (boiling point, flash point).

Analysis of many experiments shows that, compared to pure urea, NBPT-treated urea reduces NH3 losses by approximately 53\%. The average yield increase upon NBPT application is $6.0 \%$ depending on the crop species and cultivation conditions. It may range from 0.8 to $10.2 \%$ [8]. However, there are studies showing much higher efficiency of urease inhibitors. It was shown [43] that depending on soil type NBPT as a urease inhibitor contributed to reduction of the total $\mathrm{NH}_{3}$ loss by up to $85 \%$ in clay soil and up to $81 \%$ in sandy loam soil. Better results were achieved at lower soil temperature and moisture in both cases. In maize cultivation at elevated temperatures in tropical climate conditions (average temperature $26.7^{\circ} \mathrm{C}$ ), NBPT reduced urease activity for 9 days, resulting in $42 \%$ reduction of total $\mathrm{NH}_{3}$ emissions through slower release of $\mathrm{NH}_{4}{ }^{+}$into the soil solution in the urea hydrolysis process [47].

The rate of urea hydrolysis in the presence of NBPT also depends on soil $\mathrm{pH}$. The hydrolysis process is inhibited by 17.0 and $86.2 \%$ at $20{ }^{\circ} \mathrm{C}$ and by 53.3 and $92.1 \%$ at $0.5^{\circ} \mathrm{C}$ in acidic and alkaline soils, respectively. Investigations have confirmed higher stability and activity of NBPT in alkaline soils, as shown by field observations $[54,55]$. The effect of the content of soil organic matter and organic residues present on the soil surface on the NBPT yield is not clear and much less important than soil $\mathrm{pH}$ and clay content. As demonstrated on different types of soils [51], the efficiency of NBPT declines significantly (two or three times) with decrease in soil $\mathrm{pH}$.

Another commercial inhibitor, N-propylphosphorothioic triamide (NPPT), applied with urea on sandy loam soil was reported to inhibit $\mathrm{NH}_{3}$ volatilization by over $50 \%$ within 
the first 11 consecutive days after fertilisation [53]. The application of a mixture of $0.05 \%$ NPPT and $0.05 \%$ NBPT as a urease inhibitor reduced ammonia emissions by $23.8 \%$ and $28.8 \%$, compared with single applications of NBPT or NPPT, respectively [56].

The commercially available urease inhibitor mixture called Limus ${ }^{\circledR}(25 \%$ NPPT + $75 \%$ NBPT) was used at a dose of $0.12 \%(w / w$ in relation to urea) to fertilise winter wheat or maize in summer. The cumulative $\mathrm{NH}_{3}$ losses after two weeks in the case of pure urea amounted to $11-25 \%$ of $\mathrm{N}$, while only $0-6 \%$ losses were recorded when urea was supplemented with Limus ${ }^{\circledR}$. Noteworthy, compared to urea alone, the addition of Limus ${ }^{\circledR}$ reduced $\mathrm{NH}_{3}$ losses substantially by $74-100 \%$, depending on the weather conditions prevailing after fertilisation (precipitation, temperature, wind speed, etc.) [57]. Studies [10] on the effect of the Limus ${ }^{\circledR}$ urease inhibitor showed that the total $\mathrm{NH}_{3}$ loss within two weeks after application of urea without Limus ${ }^{\circledR}$ ranged from 9 to $108 \mathrm{~kg} \mathrm{~N} \mathrm{ha}^{-1}$, whereas the addition of Limus ${ }^{\circledR}$ significantly reduced the $\mathrm{NH}_{3}$ loss (on average by $84 \%$ ). Urea with Limus ${ }^{\circledR}$ did not significantly increase the yield of maize in comparison with the urea alone. The application of urea with Limus ${ }^{\circledR}$ resulted in $55-60 \%$ reduction in the dose of $\mathrm{N}$, compared to farmers' practice, and/or further $20 \% \mathrm{~N}$ savings compared to application of an optimized $\mathrm{N}$-urea dose $\left(150 \mathrm{~kg} \mathrm{~N}^{-1}\right)$.

A study [58] on the effects of different doses of NBPT-coated vs. uncoated urea on maize cultivation showed that a lower dose of NBPT-coated urea $\left(96 \mathrm{~kg} \mathrm{~N} \mathrm{ha}^{-1}\right)$ was the most suitable amount for surface application to maize in tropical climates in comparison with the normal dose of $120 \mathrm{~kg} \mathrm{~N}^{-1}$ of urea (farmers' practice). The lower dose of NBPTcoated urea successfully delayed urea hydrolysis and concurrently enhanced nitrogen bioavailability to plants.

A field experiment [59] on urea with various urease inhibitors showed that the efficiency of $\mathrm{N}$ utilization in grain was increased by incorporation of urease inhibitors in the $\mathrm{N}$ fertiliser. Additionally, the time peak of soil nitrate- $\mathrm{N}$ was delayed by 15 days, compared to conventional fertilisation. These effects were accompanied by reduced abundance of $\mathrm{N}$-cycling soil microbes. Temporal reduction in the level of bacterial ammonia monooxygenase was noted after application of DCD in an experiment on wheat grown on a sandy soil [40]. An incubation experiment on urease inhibitors showed that the action of NBPT reduced $\mathrm{N}$ losses through inhibition of the growth of ammonia-oxidizing bacteria and complete ammonia oxidation [46].

Direct analysis of physiological processes associated with $\mathrm{N}$ uptake by maize and Arabidopsis roots showed that NBPT limited plant ability to use urea as a nitrogen source [60]. Both influx and assimilation of urea were diminished by NBPT; even short-term exposure to NBPT resulted in alterations in plant metabolism ascribed to imbalance between C and N in plant cells [61]. The relatively short lifetime of NBPT in acid soils should be considered while predicting reduction of ammonia volatilization and a potential impact on crop metabolism [52,54]. According to the European Chemical Agency, the half-life time of NBPT varies strongly depending on environmental conditions: it is shorter in soil but may persist for a longer time in freshwater or freshwater sediments [54].

The studies [57-59] mentioned above confirm that the use of urease inhibitors in cultivation of maize for biofuel production offers a possibility to lower ammonia emissions by reducing nitrogen doses, thus improving the GHG production balance over the entire chain from fertiliser production to crop harvest.

The newly introduced requirements applicable to urea with urease inhibitors aim to reduce ammonia emission from soil urea by $70 \%$ and by $40 \%$ emission from liquid ammonia UAN [13]. The highly variable data from various experiments presented above indicate that the process of selecting inhibitors is not conclusive in relation to recommendations, depends on many variables such as climate, soil $\mathrm{pH}$, soil properties, etc., and requires further research assessment. Regulations concerning ammonia emission from fertilisers (or practical guidance for use of urease inhibitors) should include $\mathrm{N}$ rates, or fertilisation intensity. The proportion of $\mathrm{N}$ losses due to ammonia emission is decreasing 
with decreasing $\mathrm{N}$ rates [62-64]. Moreover, decreased efficiency of urease inhibitors in acid soils $[8,65]$ and cultivation of acid soil tolerant crops [66] is a potential challenge.

\section{Analysis of other Available Solutions}

Currently, given the small number of approved and available urease inhibitors and their complex interactions with fertilisers, soil, and climate, research on the selection of an effective urease inhibitor and its impact on the environment will obviously be continued. A review of the literature shows a wide spectrum of substances with properties of urease inhibitors (reducing nitrogen losses), e.g., phosphoramidates, hydroquinone, quinones, (di)substituted thioureas, benzothiazoles, coumarin and phenolic aldehyde derivatives, and vanadium hydrazine complexes, together with boron, copper, sulphur, zinc, ammonium thiosulfate, silver nanoparticles, oxidized charcoal, and others $[8,53,67,68]$.

One of the potential urease inhibitors is ammonium thiosulfate (ATS, $\left.\left(\mathrm{NH}_{4}\right)_{2} \mathrm{~S}_{2} \mathrm{O}_{3}\right)$ ). The first results on the application of ATS as a urease inhibitor were shown in 1990 [69,70]. ATS contains nitrogen and sulphur, compared to single-component fertilisers. Given its physicochemical properties (decomposition temperature $150^{\circ} \mathrm{C}$ [71], which is substantially higher than the melting point of urea), it is technologically possible to produce stable granules of a mixed urea-ATS fertiliser, which can potentially have more favourable properties than ATS added separately to soils.

The doses of ATS could be beneficial especially for plants of very high to medium $S$ requirements, like rape, cabbage, mustard, radish, turnip, onion, legumes, sugar beet, maize, and cotton [72].

Investigations of the application of ATS as a nitrogen-loss limiting substance have unfortunately been limited after the commercialization of the highly effective NBPT- and NPPT 2NPT-containing urease inhibitors. A granular fertiliser composed of a mixture of urea and ATS seems to have potential to reduce N losses considerably, especially in cultivation of plants with a high sulphur demand (including plants produced for the needs of biofuel production, i.e., rape, maize, sugar beet) on sandy soils [73]. The effectiveness of such a product may be higher than the separate application of urea and ATS.

The advantages of ATS as a urease inhibitor include its low cost, widespread availability, and compatibility with liquid fertiliser materials. The levels of inhibition of urea hydrolysis reported for ATS ranging from 10 to 50\% [70] are significantly lower than the levels reported for NBPT. Four variants of experiments were conducted [74] with the use of soil treated with small fertiliser drops $(0.05 \mathrm{~mL})$, soil with large drops $(0.5 \mathrm{~mL})$, soil with $50 \%$ coverage of wheat straw and small drops, and soil with $50 \%$ coverage of wheat straw and large drops at the $\mathrm{N}$ dose of $100 \mathrm{~kg} \mathrm{~N} \mathrm{ha}^{-1}$. Ammonia loss was estimated at approximately $25 \%$ of urea in an unmodified urea ammonium nitrate solution (UAN). The effectiveness of ATS was about two times lower than that of the NBPT-containing product [74].

A study [75] carried out in the use of ATS showed that the average inhibition of urea hydrolysis was increasing with increase in temperature $\left(29 \%\right.$ at $20^{\circ} \mathrm{C}$ and $37 \%$ at $\left.30{ }^{\circ} \mathrm{C}\right)$. The results of the same research indicated that ATS efficiency was shown to depend on soil moisture, reducing urea hydrolysis by $28 \%$ in soil with optimal humidity $(0.03 \mathrm{MPa})$ and $38 \%$ in drier soil $(-0.1 \mathrm{MPa})$. Thiosulfate inhibited urea hydrolysis in clay- and organic C-poor soils most effectively [75]. However, results of field experiments performed on clay and fine-grained clay soils showed low urease inhibition efficiency of ATS mixed with UAN on straw and grain yield of spring wheat [76].

It was observed that the use of $25 \mathrm{ppm}$ or $100 \mathrm{ppm}$ of S-ATS in sandy loam soil ( $\mathrm{pH} 7.8$ ) reduced ammonium production and urease activity by $37 \%$ and $68 \%$, respectively. The inhibition of urease activity in sandy soil ( $\mathrm{pH} 8.3$ ), where $70 \%$ was achieved at a lower S-ATS index and $88 \%$ at its higher value, was even more evident [77].

Comparison of the effect of different doses of ATS and NBPT on urea hydrolysis at $20^{\circ} \mathrm{C}$ showed a similar level of urea hydrolysis was inhibited by NBPT applied at a dose of 1 and $10 \mathrm{\mu g} \mathrm{g}^{-1}$ of soil by $62 \%$ and by $33 \%$ and $63 \%$ at the ATS dose of 2500 and 
$5000 \mathrm{\mu g} \mathrm{g}^{-1}$ of soil, respectively, after three days at soil $\mathrm{pH}$ 6.1. After 10 days, the levels of

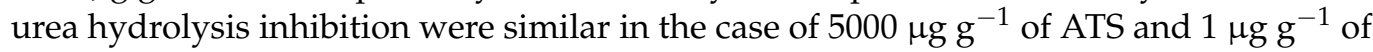
NBPT. These results were obtained for soil with a $\mathrm{pH}$ value of 6.1. The ATS results were less favourable in the case of soils with a higher $\mathrm{pH}$ value [78]. The soil microbial biomass pool was not affected using ammonium thiosulfate (ATS), which decreases urease activity in some soils [77].

Additionally, it has been found that the soil fumigation agent 1,3-dichloropropene $(1,3-\mathrm{D})$, which is emitted to the atmosphere and thus raises environmental concerns due to its toxicity and carcinogenicity, can be converted into less toxic non-volatile ions by thiosulfate fertilisers [79], an additional advantageous effect of using ATS.

The addition of ATS to urea as an inhibitor is unlikely to be as universal as NBPT and other modern and similarly highly effective inhibitors. Nevertheless, it may potentially be an effective product in certain (light) soils and may help to reduce $\mathrm{N}$ losses.

\section{Summary}

The global demand for food is growing rapidly as the world's population grows and diets change. As a result, intensified agricultural production and use of nitrogen fertilisers are observed.

Increasing agricultural production in the lowlands has serious long-term consequences for the environment. Preserving global biodiversity and minimizing the impact of ammonia and greenhouse gas emissions from agricultural production may depend on our future decisions. The EU set out in 2019 a course of action known as the Green Deal [80], which focuses on:

- more efficient use of resources through the transition to a clean and circular economy

- preventing loss of biodiversity and reducing the level of pollution

We recommend further research on dedicated solutions for the application of various types of urease inhibitors. We underline the importance of finding non-exclusive, multidirectional opportunities to reduce ammonia emissions worldwide, solutions that are cost effective, affordable for developing countries, suitable and efficient for a variety of climatic conditions and soil types.

Above all, agriculture should produce an adequate amount of raw material for food and fodder, and the rest of the agricultural land can be used for other purposes, such as the cultivation of energy crops. Currently, the production of biofuels (especially the first-generation liquid biofuels: bioethanol and biodiesel) is responsible for the conflict between food production and energy production and generates ammonia and greenhouse gas emissions. To alleviate this problem, it is necessary to implement new technologies of converting agricultural biomass into energy into production, in particular biomass obtained at the expense of food production. The use of new technologies to produce biofuels will reduce the consumption of nitrogen fertilisers and ammonia emissions to the atmosphere.

Mineral fertilisers are essential for increasing the efficiency of arable land use and ensuring global food safety. However, the management of fertilisation of crops in different climatic zones and soils with different properties, with nitrogen fertilisers containing a urease inhibitor, should be re-optimized. Such re-optimization should be directed at obtaining higher yields and reducing the impact on the environment. An analysis of the costs of fertilisation with a urease inhibitor would allow to evaluate the economic efficiency against the fertilisation without the urease inhibitors. This creates an opportunity to save natural lands, protect forests and meadows against their conversion into arable land, and conserve biodiversity.

Author Contributions: Conceptualization, M.S. and A.N.; writing-original draft preparation, M.S.; writing-review and editing, M.S. and A.N.; supervision, A.N.; funding acquisition, A.N. All authors have read and agreed to the published version of the manuscript. 
Funding: This research was partly funded by the Ministry of Science and Higher Education, Poland, grant number DWD/3/51/2019 and by statutory activities of Institute of Agrophysics, Polish Academy of Sciences, Poland.

Institutional Review Board Statement: Not applicable.

Informed Consent Statement: Not applicable.

Data Availability Statement: Data sharing not applicable.

Acknowledgments: Not applicable.

Conflicts of Interest: The authors declare no conflict of interest. The funders had no role in the design of the study; in the collection, analyses, or interpretation of data; in the writing of the manuscript, or in the decision to publish the results.

\section{Appendix A}

Table A1. Chemical composition and properties of urease inhibitors available on the market (composition and properties of formulations specified by manufacturers' MSDSs).

\begin{tabular}{|c|c|c|c|}
\hline $\begin{array}{l}\text { Name of Protease } \\
\text { Inhibitor/Reference } \\
\text { Boiling Point/ } \\
\text { Flash Point }\end{array}$ & Composition & $\begin{array}{l}\text { Proportion } \\
(\%)\end{array}$ & $\begin{array}{l}\text { Classification of the Substance acc. to } \\
\text { Regulation (WE) no. 1272/2008 (CLP) }\end{array}$ \\
\hline \multirow{3}{*}{$\begin{array}{l}\text { NBPT } 25 \% \text { Yellow for Nexur }[81] \\
\mathrm{BP}^{*}- \\
189{ }^{\circ} \mathrm{C}(\mathrm{DMSO}) \\
\mathrm{FP} * *-87(\mathrm{DMSO})\end{array}$} & $\begin{array}{l}\text { N-butyl thiophosphoric } \\
\text { triamide (NBPT) }\end{array}$ & $24-26$ & $\begin{array}{l}\text { H318 Causes serious eye damage } \\
\text { H361f Suspected of damaging fertility }\end{array}$ \\
\hline & Dimethyl sulfonide & $70-80$ & The substance is not classified as hazardous \\
\hline & Tartrazine & $<0.5$ & The substance is not classified as hazardous \\
\hline \multirow{3}{*}{$\begin{array}{l}\text { LIMUS YELLOW [82] } \\
\mathrm{BP} *-177^{\circ} \mathrm{C} \\
\mathrm{FP} * *-86^{\circ} \mathrm{C}\end{array}$} & $\begin{array}{l}\text { Post-reaction mixture of } \\
\text { compounds: } \\
\text { N-butylthiophosphoric } \\
\text { triamide (NBPT) and } \\
\text { N-propylphosphorothioic } \\
\text { triamide (NPPT) }\end{array}$ & 25 & $\begin{array}{l}\text { H319 Causes serious eye irritation } \\
\text { H302 Harmful if swallowed } \\
\text { H317 May cause an allergic skin reaction } \\
\text { H361f Suspected of damaging fertility } \\
\text { H412 Harmful to aquatic life with long-lasting } \\
\text { effects }\end{array}$ \\
\hline & Polyethyleneimine & $<25$ & $\begin{array}{l}\text { H318 Causes serious eye damage } \\
\text { H302 Harmful if swallowed } \\
\text { H317 May cause an allergic skin reaction } \\
\text { H412 Harmful to aquatic life with long-lasting } \\
\text { effects }\end{array}$ \\
\hline & Benzyl alcohol & $<45$ & $\begin{array}{l}\text { H302 Harmful if swallowed } \\
\text { H332 Harmful if inhaled } \\
\text { H319 Causes serious eye irritation } \\
\text { H312 Harmful in contact with skin }\end{array}$ \\
\hline \multirow{3}{*}{ AGROTAIN $^{\circledR}$ DRI-MAXX [83] } & $\begin{array}{l}\text { N-n-butyl thiophosphoric } \\
\text { triamide (NBPT) }\end{array}$ & $40-70$ & $\begin{array}{l}\text { H318 Causes serious eye damage } \\
\text { H361 Suspected of damaging fertility or the } \\
\text { unborn child } \\
\text { H361f Suspected of damaging fertility }\end{array}$ \\
\hline & $\begin{array}{l}\text { Component registered by } \\
\text { the manufacturer }\end{array}$ & $30-60$ & Component declared as safe by the manufacturer \\
\hline & $\begin{array}{l}\text { Pigment registered by the } \\
\text { manufacturer }\end{array}$ & $<3$ & Pigment declared as safe by the manufacturer \\
\hline StabilureN [84] & $\begin{array}{l}\text { N-n-butyl thiophosphoric } \\
\text { triamide (NBPT) }\end{array}$ & $20-30$ & $\begin{array}{l}\text { H318 Causes serious eye damage } \\
\text { H361 Suspected of damaging fertility or the } \\
\text { unborn child }\end{array}$ \\
\hline
\end{tabular}

* boiling point, ${ }^{* *}$ flash point. 


\section{References}

1. EMEP/EEA. Air Pollutant Emission Inventory Guidebook. Technical Guidance to Prepare National Emission InventoriesUpdated 2019. EEA Report No 13/2019, ISSN 1977-8449. Available online: https://www.eea.europa.eu/publications/ emep-eea-guidebook-2019/part-b-sectoral-guidance-chapters/4-agriculture/3-d-crop-production-and/view (accessed on 21 January 2021).

2. Guthrie, S.; Giles, S.; Dunkerley, F.; Tabaqchali, H.; Harshfield, A.; Ioppolo, B.; Manville, C. The impact of ammonia emissions from agriculture on biodiversity. Rand Eur. 2018. Available online: https://royalsociety.org/ \{\}/media/policy/projects/evidencesynthesis / Ammonia/Ammonia-report.pdf (accessed on 21 January 2021).

3. Food and Agriculture Organization (FAO) of the United Nations. Current World Fertiliser Trends and Outlook to 2019. 2016. Available online: http:/ / www.fao.org/documents/card/en/c/7d56821a-49ed-4e96-9420-d381fc33da22 (accessed on 21 January 2021).

4. Food and Agriculture Organization (FAO). World Fertiliser Trends and Outlook to 2022. Rome. 2019. Available online: http:/ / www.fao.org/3/ca6746en/ca6746en.pdf (accessed on 21 January 2021).

5. Directive 2001/81/EC of the European Parliament and of the Council of 23 October 2001 on national emission ceilings for certain atmospheric pollutants. Off. J. L 2001, 309, 22-30.

6. Directive 2003/35/EC of the European Parliament and of the Council of 26 May 2003 providing for public participation in respect of the drawing up of certain plans and programmers relating to the environment and amending with regard to public participation and access to justice Council Directives 85/337/EEC and 96/61/EC—Statement by the Commission. Off. J. L 2003, $156,17-25$.

7. Directive (EU) 2016/2284 of the European Parliament and of the Council of 14 December 2016 on the reduction of national emissions of certain atmospheric pollutants, amending Directive 2003/35/EC and repealing Directive 2001/81/EC. Off. J. L 2016, $344,1-31$.

8. Cantarella, H.; Otto, R.; Soares, J.R.; de Brito Silva, A.G. Agronomic efficiency of NBPT as a urease inhibitor. A review. J. Adv. Res. 2018, 13, 19-27. [CrossRef]

9. Saggar, S.; Singh, J.; Giltrap, D.L.; Zaman, M.; Luo, L.; Rollo, M.; Kim, D.-G.; Rys, G.; van der Weerden, T.J. Quantification of reductions in ammonia emissions from fertiliser urea and animal urine in grazed pastures with urease inhibitors for agriculture inventory, New Zealand as a case study. Sci. Total Environ. 2013, 465, 136-146. [CrossRef] [PubMed]

10. Li, Q.; Cui, X.; Liu, X.; Roelcke, M.; Pasda, G.; Zerulla, W.; Wissemeier, A.H.; Chen, X.; Goulding, K.; Zhang, F. A new ureaseinhibiting formulation decreases ammonia volatilization and improves maize nitrogen utilization in North China Plain. Sci. Rep. 2017, 7, 43853. [CrossRef]

11. International Fertilisers Association (IFA). Market Intelligence and Agriculture Services. Fertiliser Outlook 2020-2024. 2020. Available online: https: / /www.ifastat.org/market-outlooks9 (accessed on 21 January 2021).

12. Fertilisers Europe. Towards Smart Agriculture 2019. Available online: https://www.fertiliserseurope.com/wp-content/uploads/ 2019/08/Nitrate_Smart_Agriculture_FINAL_version.pdf (accessed on 21 January 2021).

13. Bittman, S.; Dedina, M.; Howard, C.M.; Oenema, O.; Sutton, M.A. Options for Ammonia Mitigation Guidance from the UNECE Task Force on Reactive Nitrogen; Centre for Ecology and Hydrology (CEH): Edinburgh, UK, 2014; ISBN 978-1-906698-46-1.

14. Tudge, S.J.; Purvis, A.; De Palma, A. The impacts of biofuel crops on local biodiversity: A global synthesis. Biodivers Conserv. 2021, 1-21. [CrossRef]

15. Kurowska, K.; Marks-Bielska, R.; Bielski, S.; Kryszk, H.; Jasinskas, A. Food Security in the Context of Liquid Biofuels Production. Energies 2020, 13, 6247. [CrossRef]

16. Elobeid, A.A.; Carriquiry, M.; Dumortier, J.; Rosas, J.F.; Mulik, K.; Fabiosa, J.F.; Hayes, D.J.; Babcock, B.A. Biofuel Expansion, Fertiliser Use, and GHG Emissions: Unintended Consequences of Mitigation Policies. Econ. Res. Int. 2013, $2013,708604$. [CrossRef]

17. Food and Agricultural Organization (FAO). How to Feed the World in 2050 [Internet]. 2009. Available online: http:/ /www.fao. org/fileadmin/templates/wsfs/docs/expert_paper/How_to_Feed_the_World_in_2050.pdf (accessed on 21 January 2021).

18. Alexandratos, N.; Bruinsma, J. World Agriculture towards 2030/2050. The 2012 Revision. Global Perspective Studies. 2012, Team ESA Working Paper No. 12-03. Available online: http:/ /www.fao.org/3/ap106e/ap106e.pdf (accessed on 21 January 2021).

19. Sutton, M.A.; Reis, S.; Riddick, S.N.; Dragosits, U.; Nemitz, E.; Theobald, M.R.; Sim Tang, Y.; Braban, C.F.; Vieno, M.; Dore, A.J.; et al. Towards a climate-dependent paradigm of ammonia emission and deposition. Philos. Trans. R. Soc. B Biol. Sci. 2013, 368, 20130166. [CrossRef] [PubMed]

20. Sapek, A. Ammonia Emissions from Non-Agricultural Sources. Pol. J. Environ. Stud. 2013, 13, 95-110.

21. Kanakidou, M.; Myriokefalitakis, S.; Daskalakis, N. Past, Present and Future Atmospheric Nitrogen Deposition. J. Atmos. Sci. 2016, 73, 2039-2047. [CrossRef]

22. Pinder, R.W.; Adams, P.J.; Pandis, S.N.; Gilliland, A.B. Temporally resolved ammonia emission inventories: Current estimates, evaluation tools, and measurement needs. J. Geophys. Res. 2006, 111, D16. [CrossRef]

23. Krupa, S.V. Effects of atmospheric ammonia (NH3) on terrestrial vegetation: A review. Environ. Pollut. 2003, 124, 179-221. [CrossRef]

24. Kavanagh, I.; Fenton, O.; Healy, M.G.; Burchill, W.; Lanigan, G.J.; Krol, D.J. Mitigating ammonia and greenhouse gas emissions from stored cattle slurry using agricultural waste, commercially available products and a chemical acidifier. J. Clean. Prod. 2021, 294, 12625. [CrossRef] 
25. Vallero, D.A. Air Pollution Calculations Quantifying Pollutant Formation, Transport, Transformation, Fate and Risks; Elsevier: Amsterdam, The Netherlands, 2019; Chapter 8; pp. 175-206. ISBN 9780128149355. [CrossRef]

26. Erisman, J.W.; van Grinsven, H.; Leip, A.; Mosier, A. Nitrogen and biofuels; an overview of the current state of knowledge. Nutr. Cycl. Agroecosyst. 2009, 86, 211-223. [CrossRef]

27. Makowski, D. $\mathrm{N}_{2} \mathrm{O}$ increasing faster than expected. Nat. Clim. Chang. 2019, 9, 909-910. [CrossRef]

28. Subramaniam, Y.; Masron, T.M.; Hadiyan, N.; NikAzman, N. The Impact of Biofuels on Food Security. International Economics, 2019. Available online: https:/ / doi.org/10.1016/j.inteco.2019.10.003 (accessed on 21 January 2021). [CrossRef]

29. Ghosh, P.; PatrickWesthoff, P.; Debnath, D. Biofuels, food security, and sustainability. In Biofuels, Bioenergy and Food Security: Technology, Institutions and Policies; Academic Press: Cambridge, MA, USA, 2019; pp. 211-229.

30. Crutzen, P.J.; Mosier, A.R.; Smith, K.A.; Winiwarter, W. $\mathrm{N}_{2} \mathrm{O}$ release from agro-biofuel production negates global warming reduction by replacing fossil fuels. Atmos. Chem. Phys. 2008, 8, 389-395. [CrossRef]

31. International Energy Agency (IEA). Renewables 2019: Analysis and Forecasts to 2024; IAE: Paris, France, 2019. [CrossRef]

32. Simić, M.; Dragičević, V.; Mladenović Drinić, S.; Vukadinović, J.; Kresović, B.; Tabaković, M.; Brankov, M. The Contribution of Soil Tillage and Nitrogen Rate to the Quality of Maize Grain. Agronomy 2020, 10, 976. [CrossRef]

33. Gołębiewska, M.; Wróbel, E. The effect of nitrogen fertilisation on yielding of maize. Bull. Plant Breed. Acclim. Inst. 2009, 251, 121-136.

34. Sapkota, A.; Shrestha, R.K.; Chalise, D. Response of Maize to the Soil Application of Nitrogen and Phosphorous Fertilisers. Int. J. Appl. Sci. Biotechnol. 2017, 5, 537-541. [CrossRef]

35. Ma, R.; Han, J.Z.Z.; Yu, K.; Wu, S.; Li, Z.; Liu, S.; Niu, S.; Horwath, W.R.; Zhu-Barker, X. Global soil-derived ammonia emissions from agricultural nitrogen fertiliser application: A refinement based on regional and crop-specific emission factors. Glob. Chang. Biol. 2020, 27, 855-867. [CrossRef] [PubMed]

36. Skoufogianni, E.; Solomou, A.; Charvalas, G.; Danalatos, N. Maize as Energy Crop. In Maize-Production and Use; Hossain, A., Ed.; IntechOpen: London, UK, 2019; Available online: https://www.intechopen.com/books/maize-production-and-use/maize-asenergy-cropIntechOpen (accessed on 21 January 2021). [CrossRef]

37. Jankowski, K.J.; Dubis, B.; Sokólski, M.M.; Załuski, D.; Bórawski, P.; Szempliński, W. Productivity and energy balance of maize and sorghum grown for biogas in a large-area farm in Poland: An 11-year field experiment. Ind. Crop. Prod. 2020, 148, 112326. [CrossRef]

38. Gallagher, M.E.; William Hockaday, W.C.; Masiello, C.A.; Snapp, S.; McSwiney, C.P.; Baldock, J.A. Biochemical Disincentives to Fertilizing Cellulosic Ethanol Crops. Environ. Sci. Technol. 2011, 45, 2013-2020. [CrossRef] [PubMed]

39. Cronin, J.; Zabel, F.; Dessens, O.; Anandarajah, G. Land suitability for energy crops under scenarios of climate change and land-use. GCB Bioenergy 2020, 12, 648-665. [CrossRef]

40. Fu, Q.; Abadie, M.; Blaud, A.; Carswell, A.; Misselbrook, T.H.; Clark, I.M.; Hirsh, P.H. Effects of urease and nitrification inhibitors on soil N, nitrifier abundance and activity in a sandy loam soil. Biol. Fertil. Soils 2020, 56, 185-194. [CrossRef] [PubMed]

41. Wesołowska, M.; Rymarczyk, J.; Góra, R.; Baranowski, P.; Sławiński, C.; Klimczyk, M.; Supryn, G.; Schimmelpfennig, L. New slow-release fertilisers-Economic, legal and practical aspects: A Review. Int. Agrophys. 2021, 35, 11-24. [CrossRef]

42. Pan, B.; Lam, S.K.; Mosiera, A.; Luo, Y.; Chena, D. Ammonia volatilization from synthetic fertilisers and its mitigation strategies: A global synthesis. Agric. Ecosyst. Environ. 2016, 232, 283-289. [CrossRef]

43. Rawluk, C.D.L.; Grant, C.A.; Racz, G.J. Ammonia volatilization from soils fertilised with urea and varying rates of urease inhibitor NBPT. Can. J. Soil Sci. 2001, 81, 234-246. [CrossRef]

44. Jadon, P.; Selladurai, R.; Yadav, S.S.; Coumar, V.M.; Dotaniya, M.L.; Singh, A.K.; Bhadouriya, J.; Kundu, S. Volatilization and leaching losses of nitrogen from different coated urea fertilisers. J. Soil Sci. Plant Nutr. 2018, 18, 1036-1047. [CrossRef]

45. Saggar, S.; Jha, N.; Deslippe, J.; Bolan, N.S.; Luo, J.; Giltrap, D.L.; Kim, D.-G.; Zaman, M.; Tillman, R.W. Denitrification and N 2 O:N 2 production in temperate grasslands: Processes, measurements, modelling and mitigating negative impacts. Sci. Total Environ. 2012, 465, 173-195. [CrossRef]

46. Luchibia, A.O.; Suter, H.; Hu, H.W. Responses of ureolytic and nitrifying microbes to urease and nitrification inhibitors in selected agricultural soils in Victoria, Australia. J. Soils Sediments 2020, 20, 1309-1322. [CrossRef]

47. Sanz-Cobena, A.; Misselbrook, T.H.; Arce, A.; Mingot, J.I.; Diez, J.A.; Vallejo, A. An inhibitor of urease activity effectively reduces ammonia emissions from soil treated with urea under Mediterranean conditions. Agric. Ecosyst. Environ. 2008, 126, 243-249. [CrossRef]

48. Nitrogen +Syngas. Nitrogen Project Listing, 2018, 352, March April. Available online: https://www.bcinsight.com/nitrogen_ syngas.asp (accessed on 21 January 2021).

49. European Commission. (BAT), Reference Document on Best Available Techniques for the Manufacture of Large Volume Inorganic Chemicals-Ammonia. Acids Fertil. 2007, 8, 352-364.

50. Bock, B.R.; Kissel, D.E. Ammonia Volatization from Urea Fertilisers; National Fertiliser Development Center Tennessee Valley Authority Muscle Shoals: Tuscaloosa, AL, USA, 1988; pp. 51-76. ISBN 0-87077-003-9.

51. Francisco, S.S.; Urrutia, O.; Martin, V.; Peristeropoulosa, A.; Garcia-Minaa, J.M. Efficiency of urease and nitrification inhibitors in reducing ammonia volatilization from diverse nitrogen fertilisers applied to different soil types and wheat straw mulching. J. Sci. Food Agric. 2011, 91, 1569-1575. [CrossRef] [PubMed] 
52. Byrne, M.P.; Tobin, J.T.; Forrestal, P.J.; Chikere, M.D.; Nkwonta, G.; Richards, K.; Cummins, E.; Hoganand, S.A.; O'Callaghan, T.F. Urease and Nitrification Inhibitors-As Mitigation Tools for Greenhouse Gas Emissions in Sustainable Dairy Systems: A Review. Sustainability 2020, 12, 6018. [CrossRef]

53. Modolo, L.V.; da-Silva, C.J.; Brandão, D.S.; Chaves, I.S. A minireview on what we have learned about urease inhibitors of agricultural interest since mid-2000sq. J. Adv. Res. 2018, 13, 29-37. [CrossRef]

54. Engel, R.E.; Towey, B.D.; Gravens, E. Degradation of the Urease Inhibitor NBPT as Affected by Soil pH. Soil Sci. Soc. Am. J. 2015, 79, 1674-1683. [CrossRef]

55. Engel, R.E.; Williams, E.; Wallander, R.; Hilmer, J. Apparent Persistence of N-(n-butyl) Thiophosphoric Triamide Is Greater in Alkaline Soils. Soil Sci. Soc. Am. J. 2013, 77, 1424-1429. [CrossRef]

56. Gans, W.; Herbst, F.; Merbach, W. Nitrogen balance in the system plant-Soil after urea fertilisation combined with urease inhibitors. Plant Soil Environ. 2006, 52, 36-38.

57. Li, Q.; Yang, A.; Wang, Z.; Roelcke, M.; Chen, X.; Zhang, F.; Pasda, G.; Zerulla, W.; Wissemeier, A.H.; Liu, X. Effect of a new urease inhibitor on ammonia volatilization and nitrogen utilization in wheat in north and northwest China. Field Crop. Res. 2015, 175, 96-105. [CrossRef]

58. Zuki, M.M.M.Z.; Jaafar, N.M.; Sakimin, S.Z.; Yusop, M.K. N-(n-Butyl) Thiophosphoric Triamide (NBPT)-Coated Urea (NCU) Improved Maize Growth and Nitrogen Use Efficiency (NUE) in Highly Weathered Tropical Soil. Sustainability 2020, $12,8780$. [CrossRef]

59. Liu, G.; Yang, Z.; Du, J.; He, A.; Yang, H.; Xue, G. Adding NBPT to urea increases N use efficiency of maize and decreases the abundance of $\mathrm{N}$-cycling soil microbes under reduced fertiliser-N rate on the North China Plain. PLoS ONE 2020, 15, e0240925. [CrossRef]

60. Zanin, L.; Tomasi, N.; Zamboni, A.; Varanini, Z.; Pinton, R. The Urease Inhibitor NBPT Negatively Affects DUR3-mediated Uptake and Assimilation of Urea in Maize Roots. Front. Plant Sci. 2015, 6, 1007. [CrossRef] [PubMed]

61. Zanin, L.; Venuti, S.; Tomasi, N.; Zamboni, A.; De Brito Francisco, R.M.; Varanini, Z.; Pinton, R. Short-Term Treatment with the Urease Inhibitor N-(n-Butyl) Thiophosphoric Triamide (NBPT) Alters Urea Assimilation and Modulates Transcriptional Profiles of Genes Involved in Primary and Secondary Metabolism in Maize Seedlings. Front. Plant Sci. 2016, 7, 845. [CrossRef] [PubMed]

62. Wan, X.; Wu, W.; Shah, F. Nitrogen fertilizer management for mitigating ammonia emission and increasing nitrogen use efficiencies by $15 \mathrm{~N}$ stable isotopes in winter wheat. Sci. Total Environ. 2021, 790, 147587. [CrossRef] [PubMed]

63. Klimczyk, M.; Siczek, A.; Schimmelpfennig, L. Improving the efficiency of urea-based fertilization leading to reduction in ammonia emission. Sci. Total Environ. 2021, 771, 145483. [CrossRef]

64. Huang, S.; Lv, W.; Bloszies, S.; Shi, Q.; Pan, X.; Zeng, Y. Effects of fertilizer management practices on yield-scaled ammonia emissions from croplands in China: A meta-analysis. Field Crop. Res. 2016, 192, 118-125. [CrossRef]

65. Rochette, P.; Angers, D.A.; Chantigny, M.H.; Gasser, M.O.; Mac-Donald, J.D.; Pelster, D.E.; Bertrand, N. NH3 volatilization, soil concentration and soil $\mathrm{pH}$ following subsurface banding of urea at in-creasing rates. Can. J. Soil Sci. 2013, 93, 261-268. [CrossRef]

66. Siecińska, J.; Wiacek, D.; Przysucha, B.; Nosalewicz, A. Drought in acid soil in-creases aluminum toxicity especially of the Al-sensitive wheat. Environ. Exp. Bot. 2019, 165, 185-195. [CrossRef]

67. Svane, S.; Sigurdarson, J.J.; Finkenwirth, F.; Eitinger, T.; Karring, H. Inhibition of urease activity by different compounds provides insight into the modulation and association of bacterial nickel import and ureolysis. Sci. Rep. 2020, 10, 8503. [CrossRef] [PubMed]

68. Kappaun, K.; Piovesan, A.R.; Carlini, C.R.; Ligabue-Braun, R. Ureases: Historical aspects, catalytic, and non-catalytic propertiesA review. J. Adv. Res. 2018, 13, 3-17. [CrossRef] [PubMed]

69. Goos, R.J. Identification of Ammonium Thiosulfate as a Nitrification and Urease Inhibitor. Soil Sci. Soc. Am. J. 1985, 49, 232-235. [CrossRef]

70. Goos, R.J. Ammonium thiosulfate as a urease inhibitor a suggested mechanism. In Proceedings of the Seventeen North Central Extension-Industry Soil Fertility Workshop, St. Louis, MO, USA, 28-29 October 1987.

71. Safety Data Sheet ATS. Available online: https://www.finarchemicals.com/msds/Ammonium\%20thiosulphate.pdf (accessed on 21 January 2021).

72. Podleśny, A. Studies on Role of Sulphur at Forming of Mineral Management and Height and Quality of Chosen Crops Yield; Institute of Soil Science and Plant Cultivation, State Research Institute: Puławy, Poland, 2013; pp. 18-23. ISBN 978-83-7562-133-4.

73. Goos, R.J. Evaluation of Two Products Recently Introduced as Nitrification Inhibitors. Commun. Soil Sci. Plant Anal. 2019, 50, 503-511. [CrossRef]

74. Goos, R.J. Nitrogen fertiliser additives, which ones work. In Proceedings of the North Central Extension-Industry Soil Fertility Conference, Des Moines, IA, USA, 16-17 November 2011; Volume 27.

75. Sullivan, D.M.; Havlin, J.L. Soil and Environmental Effects on Urease Inhibition by Ammonium Thiosulfate. Soil Sci. Soc. Am. J. 1992, 56, 950-956. [CrossRef]

76. Grant, C.A. Use of NBPT and ammonium thiosulphate as urease inhibitors with varying surface placement of urea and urea ammonium nitrate in production of hard red spring wheat under reduced tillage management. Can. J. Plant Sci. 2014, 94, 329-335. [CrossRef]

77. Margon, A.; Parente, G.; Piantanida, M.; Cantone, P.; Leita, L. Novel Investigation on Ammonium Thiosulphate (ATS) as an Inhibitor of Soil Urease and Nitrification. Int. J. Agric. Sci. 2015, 6, 1502-1512. [CrossRef] 
78. McCarty, G.W.; Bremner, J.M.; Krogmeier, M.J. Evaluation of ammonium thiosulfate as a soil urease inhibitor. Fertil. Res. 1990, 24, 135-139. [CrossRef]

79. Gan, J.; Becker, L.O.; Ernst, F.F.; Hutchinson, C.; Knuteson, J.A.; Yates, S.R. Surface application of ammonium thiosulfate fertiliser to reduce volatilization of 1,3-dichloropropene from soil. Pest. Manag. Sci. 2000, 56, 264-270. [CrossRef]

80. European Commission. The European Green Deal. Available online: https://ec.europa.eu/info/sites/info/files/europeangreen-deal-communication_en.pdf (accessed on 21 January 2021).

81. Safety Data Sheet NBPT 25\% Yellow for Nexur. Date of issue 20.02.2019, revision date 20.02.2019, version 1.0. Manufacturer's leaflet supplied with the product.

82. Safety Data Sheet Limus Yellow. Available online: https://www.raiffeisen.com/agrar_sdb/detail/20353 (accessed on 21 January 2021).

83. Safety Data Sheet Agrotein Dri Maxx. Available online: https://kochfertilizer.com/sds (accessed on 21 January 2021).

84. Data Sheet StabilureN. Available online: https://www.agra.cz/obj/files/2/sys_media_1431.pdf (accessed on 21 January 2021). 